\title{
The function of CUX1 in oxidative DNA damage repair is needed to prevent premature senescence of mouse embryo fibroblasts
}

\author{
Zubaidah M. Ramdzan ${ }^{1}$, Ranjana Pal ${ }^{1,5}$, Simran Kaur ${ }^{1,2}$, Lam Leduy ${ }^{1}$, \\ Ginette Bérubé ${ }^{1}$, Sayeh Davoudi ${ }^{1,2}$, Charles Vadnaiss ${ }^{1,2}$, Alain Nepveu ${ }^{1,2,3,4}$ \\ ${ }^{1}$ Goodman Cancer Centre, McGill University, Montreal, Quebec H3A 1A3, Canada \\ ${ }^{2}$ Department of Biochemistry, McGill University, Montreal, Quebec H3A 1A3, Canada \\ ${ }^{3}$ Department of Medicine, McGill University, Montreal, Quebec H3A 1A3, Canada \\ ${ }^{4}$ Department of Oncology, McGill University, Montreal, Quebec H3A 1A3, Canada \\ ${ }^{5}$ Department of Biological Sciences, Presidency University, Kolkata 700073, India \\ Correspondence to: \\ Alain Nepveu, e-mail: alain.nepveu@mcgill.ca \\ Keywords: cellular senescence, mouse embryo fibroblasts, oxidative DNA damage, 8-oxoguanine DNA glycosylase 1 (OGG1), CUX1 \\ Received: November 17, $2014 \quad$ Accepted: December 11,2014 Published: February 17, 2015
}

\section{ABSTRACT}

Despite having long telomeres, mouse embryo fibroblasts (MEFs) senesce more rapidly than human diploid fibroblasts because of the accumulation of oxidative DNA damage. The CUX1 homeodomain protein was recently found to prevent senescence in RAS-driven cancer cells that produce elevated levels of reactive-oxygen species. Here we show that Cux1-/- MEFs are unable to proliferate in atmospheric (20\%) oxygen although they can proliferate normally in physiological (3\%) oxygen levels. CUX1 contains three domains called Cut repeats. Structure/function analysis established that a single Cut repeat domain can stimulate the DNA binding, Schiff-base formation, glycosylase and AP-lyase activities of 8-oxoguanine DNA glycosylase 1, OGG1. Strikingly and in contrast to previous reports, OGG1 exhibits efficient AP-lyase activity in the presence of a Cut repeat. Repair of oxidative DNA damage and proliferation in $20 \%$ oxygen were both rescued in Cux1-/- MEFs by ectopic expression of CUX1 or of a recombinant Cut repeat protein that stimulates OGG1 but is devoid of transcription activation potential. These findings reinforce the causal link between oxidative DNA damage and cellular senescence and suggest that the role of CUX1 as an accessory factor in DNA repair will be critical in physiological situations that generate higher levels of reactive oxygen species.

\section{INTRODUCTION}

The presence of senescent cells is associated with, and is believed to contribute to, many age-related pathologies $[1,2]$. Cellular senescence is triggered by many types of genomic damage, including telomere shortening and oxidative DNA damage [3]. For example, MEFs have long telomeres and express telomerase but senesce more rapidly than human diploid fibroblasts because of the accumulation of oxidative DNA damage [4]. MEFs become senescent after 4 to 5 weeks when cultured in $20 \%$ oxygen, but proliferate indefinitely when maintained in 3\% oxygen [4]. Moreover, MEFs cultured in $3 \%$ oxygen for $10-15$ population doublings eventually undergo a mutagenic or adaptive event that allows them to proliferate in $20 \%$ oxygen [4].
Reactive oxygen species (ROS) produced by external sources or generated through cellular metabolism represent a major threat to the integrity of DNA. Among the most deleterious of ROS-induced adducts in DNA is 7,8-dihydro-8-oxoguanine (8-oxoG), which can mispair with adenine and cause G-C to T-A transversion mutations [5]. 8-oxoG lesions are removed by base excision repair, a process that is initiated by specific DNA glycosylases. In human cells, oxidative purine lesions are removed by 8-oxoguanine DNA glycosylase 1, OGG1, whereas oxidative pyrimidine lesions are removed by NTH1, NEIL1, or NEIL2 (reviewed in [6]). DNA glycosylases for oxidized bases are bifunctional. These enzymes hydrolyze the $\mathrm{N}$-glycosidic bond to generate an apurinic/apyridinic (AP) site and then generate a single-strand nick 3 ' to the 
AP site via beta (OGG1, NTH1) or beta-delta (NEIL1, NEIL2) elimination. End-processing of the resulting single-strand break is then performed by APE1 or PNKP, and repair synthesis and ligation are accomplished by the short-patch or long-patch pathways [7, 8].

Deficient repair of oxidative DNA damage has been implicated in both cancer development and neurodegenerative disorders [9]. Functional analysis of DNA repair enzymatic activity showed that reduced activity of OGG1 is a risk factor in lung and head and neck cancer $[10,11]$. The regulation of OGG1 activity may occur through a variety of mechanisms including transcriptional control, protein-protein interactions, posttranslational modifications and dynamic localization, however, none of these mechanisms can explain the observed differences among individuals [12]. The existence of single nucleotide polymorphisms in the human OGG1 gene has triggered a number of epidemiological studies to evaluate the association with sporadic cancers. Overall, these studies led to conflicting results and suggest a minor effect at best [13].

The Cut homeobox 1 gene, $C U X 1$, has been implicated in both tumor suppression and tumor progression. While CUX1 is the target of monoallelic deletion or inactivating somatic mutations in many cancers, increased CUX1 expression is associated with shorter disease-free survival (reviewed in [14]). Indeed, transgenic mice expressing specific CUX1 isoforms develop tumors or cancer-associated disorders in various tissues [15-21]. The biochemical and cellular functions of CUX1 involved in tumor suppression and/ or progression remain to be fully characterized. CUX1 encodes two main isoforms with strikingly different properties (reviewed in $[22,23]$ ). The proteolytically processed p110 CUX1 isoform makes a stable interaction with DNA and functions as a transcriptional repressor or activator depending on the promoter context [2426]. Much less is known about the biochemical and cellular functions of the full-length protein, p200 CUX1. This isoform is very abundant and binds DNA with extremely fast kinetics (rapid "on" and "off" rates), using four evolutionarily conserved DNA binding domains: three Cut repeats (CR1, CR2 and CR3) and a Cut homeodomain (HD) [27]. These properties are not consistent with a role as a classical transcription factor that binds stably to a limited number of genomic sites where it recruits a co-activator or a co-repressor. Indeed, we have recently uncovered a direct role of p200 CUX1 in DNA repair [16]. Knockdown or genetic inactivation of CUX1 delays, whereas ectopic p200 CUX1 expression, accelerates repair of DNA damage. In vitro, recombinant CUX1 proteins stimulate the glycosylase activity of OGG1 on oligonucleotides containing an 8-oxoguanine. Elevated CUX1 expression prevents senescence caused by a RAS oncogene in human primary cells and cooperates with RAS in promoting tumorigenicity in the mouse [16]. As CUX1 knockdown is synthetic lethal for cells that harbor a RAS oncogene $[16,28]$, these findings established a case of non-oncogene addiction whereby RAS-driven cancer cells have become acutely dependent on the heightened expression and activity of a normal protein, p200 CUX1, that is not itself oncogenic (reviewed in $[29,30]$ ).

In the present study, we used mouse embryo fibroblasts derived from a Cux $1^{-/}$knockout mouse to investigate the physiological role of CUX1 in oxidative DNA damage repair. Proliferation assays indicate that CUX1 is required for cells to avoid senescence and continue to proliferate in the presence of oxidative stress. Structure-function analysis and in vitro assays with purified components established that a single Cut repeat domain is sufficient to stimulate many biochemical activities of OGG1 including DNA binding, Schiff-base formation, glycosylase and AP-lyase reactions.

\section{RESULTS}

\section{Genetic inactivation of $\mathrm{Cux} 1$ causes a proliferation block in atmospheric $(20 \%)$ oxygen}

Since the perinatal lethality of $\mathrm{Cux}^{-/-}$knockout mice precludes further phenotypic analysis, we employed mouse embryo fibroblasts (MEFs) to investigate the consequences of CUX1 inactivation (Figure 1A). We compared the proliferative capacity of $\mathrm{Cux}^{+/+}$and $\mathrm{Cux}^{1^{-/}}$ MEFs in $3 \%$ and $20 \%$ oxygen. While $\mathrm{Cux}^{-/-}$MEFs proliferated slightly more slowly than $\mathrm{Cux}^{+/ /+} \mathrm{MEFs}$ in $3 \%$ oxygen, they exhibited a drastic proliferation defect in $20 \%$ oxygen (Figure 1B). The striking proliferation block in $20 \%$ oxygen suggested that $\mathrm{Cux1}^{-/}$MEFs were sensitive to oxidative stress. Indeed, $\mathrm{Cux}^{-1^{--}} \mathrm{MEFs}$ exhibited hypersensitivity to treatment with increasing concentrations of $\mathrm{H}_{2} \mathrm{O}_{2}$ (Figure 1C). We therefore compared the capacity of these cells to repair oxidative DNA damage. $\mathrm{Cux}^{+/ /+}$and $\mathrm{Cux}^{-/-} \mathrm{MEFs}$, maintained in $3 \%$ oxygen for 7 days, were treated with $\mathrm{H}_{2} \mathrm{O}_{2}$ and submitted to single cell gel electrophoresis (comet assay) after variable recovery periods. Comet assays performed at $\mathrm{pH}>13$ showed that the repair of oxidative DNA damage is delayed in $\mathrm{Cux}^{1^{-/}}$MEFs (Figure 1D). Comet assays in these alkaline conditions $(\mathrm{pH}>13)$ detect doublestrand and single-strand breaks as well as abasic sites and several types of altered bases that are intrinsically labile at high $\mathrm{pH}$. In contrast, comet assays performed at $\mathrm{pH}$ 10 only detects double-strand breaks and single-strand breaks (Figure 1E). Addition of the formamidopyrimidine DNA glycosylase (FPG) allows the detection of most types of oxidized bases, including 8-oxoG and formamidopyrimidines. Treatment with FPG indicated that the repair of oxidized bases is delayed in $\mathrm{Cux} 1^{-/}$ MEFs, pointing to a specific defect in base excision repair, particularly in the repair of oxidized bases (Figure 1F). 

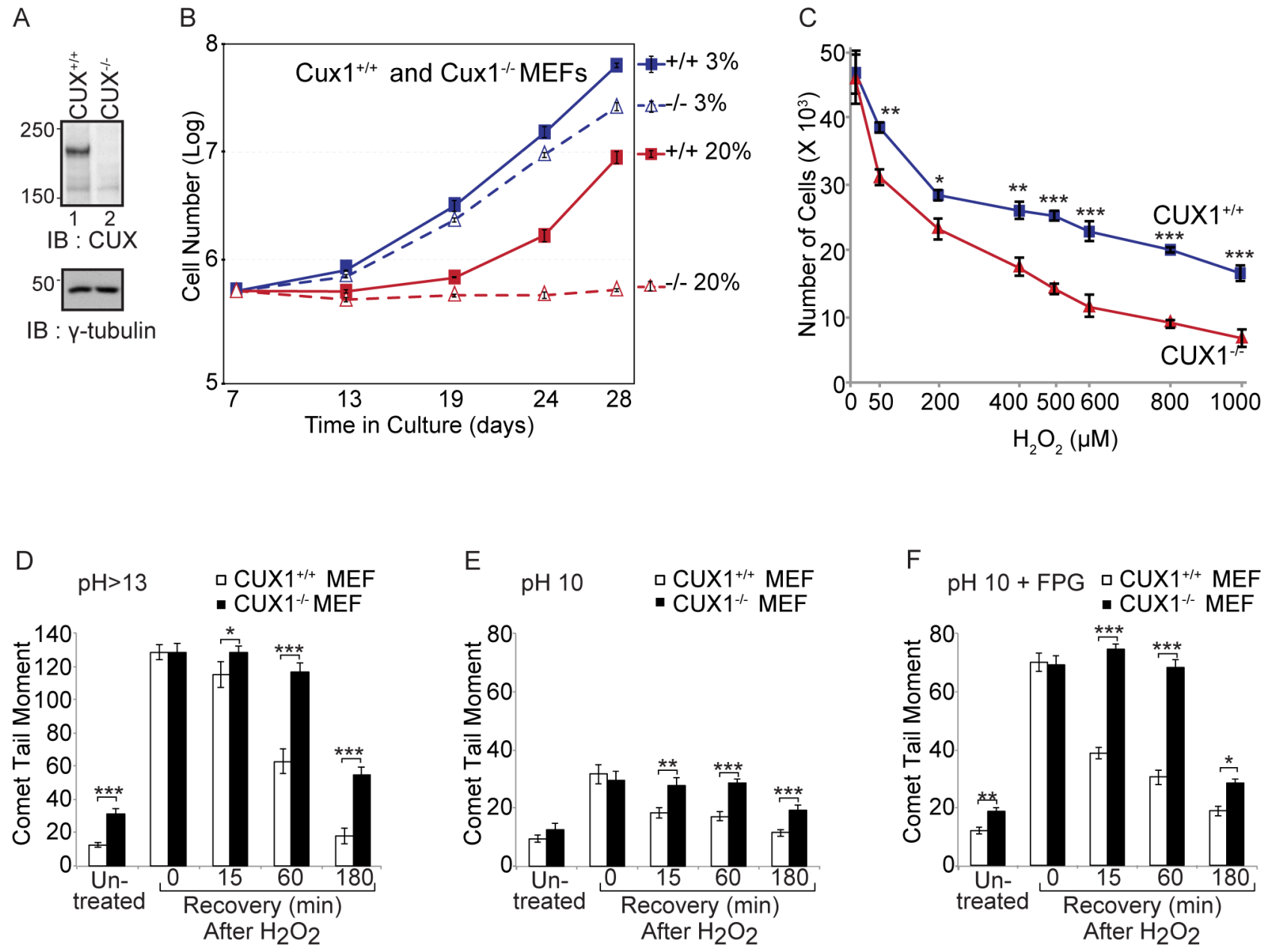

Figure 1: Genetic inactivation of Cux1 causes a proliferation block in atmospheric (20\%) oxygen. (A) Immunoblotting analysis using CUX1-1300 antibody. (B) Cux ${ }^{1 /+}$ and Cux $1^{-/}$MEFs were cultured in 3\% or 20\% oxygen and counted over a period of 21 days. (C) $\mathrm{Cux}_{1}^{+/+}$and $\mathrm{Cux}^{-/}$MEFs were maintained in $3 \%$ oxygen for 7 days and exposed to various concentration of $\mathrm{H}_{2} \mathrm{O}_{2}$ for 60 min and then cultured in fresh medium for $24 \mathrm{~h}$ in $3 \%$ oxygen before counting the cells. Error bars represent standard error. $* p<0.05, * * p<$ $0.01,{ }^{* * *} p<0.001$; Student's $t$-test. (D, E and F) $\mathrm{Cux}^{+/ /}$and Cux $1^{-/-}$MEFs were maintained in $3 \%$ oxygen for 7 days, exposed to $50 \mu \mathrm{M}$ $\mathrm{H}_{2} \mathrm{O}_{2}$ for 20 minutes and allowed to recover for the indicated time. Cells were submitted to single cell gel electrophoresis at $\mathrm{pH}>13$ (D), $\mathrm{pH} 10$ (E), and $\mathrm{pH} 10$ in the presence of FPG (F) Comet tail moments were scored for at least 50 cells per condition. Error bars represent standard error. ${ }^{*} p<0.05,{ }^{* *} p<0.01,{ }^{* * *} p<0.001$; Student's $t$-test.

\section{A recombinant $\mathrm{CUX1}$ protein that is devoid of transcriptional activity can prevent the accumulation of oxidative DNA damage}

$\mathrm{Cux}^{--}$MEFs carrying an empty vector and maintained in $3 \%$ oxygen can proliferate but gradually accumulate oxidative DNA damage, as revealed by comet assays performed on day 32 (Figure 2B, and 2E; compare with comet assays of untreated cells in Figure 1D, and 1F). DNA damage, however, was greatly reduced by ectopic expression of p200 or p110 CUX1, the main two isoforms of CUX1 (Figure 2A and 2E). The increase in DNA repair capacity conferred by CUX1 expression could involve a transcriptional or a non-transcriptional role of CUX1 in DNA repair, since the p110 CUX1 isoform has previously been shown to activate the expression of many genes involved in DNA damage responses [31]. To examine the possibility of a non-transcriptional role of CUX1 in DNA repair, we engineered a retroviral vector to express a recombinant protein encompassing the Cut repeats 1 and 2 fused to a nuclear localization signal, CR1CR2-NLS (see map in Figure 2A). This protein exhibits very fast DNA binding kinetics and lacks the amino acids required for transcriptional activation [27, 32]. Indeed, gene expression analysis confirmed that transcriptional targets of p110 CUX1 that are involved in DNA damage responses were not upregulated in $\mathrm{Cux}^{-/-}$MEFs stably expressing CR1CR2-NLS (Figure 2F). Yet, CR1CR2-NLS reduced DNA damage in MEFs despite its inability to activate transcription (Figure 2C, and 2E). These findings suggest that CUX1 may play a direct role in the repair of oxidized bases in addition to its role as a transcriptional activator of DNA damage response genes [31]. 
A

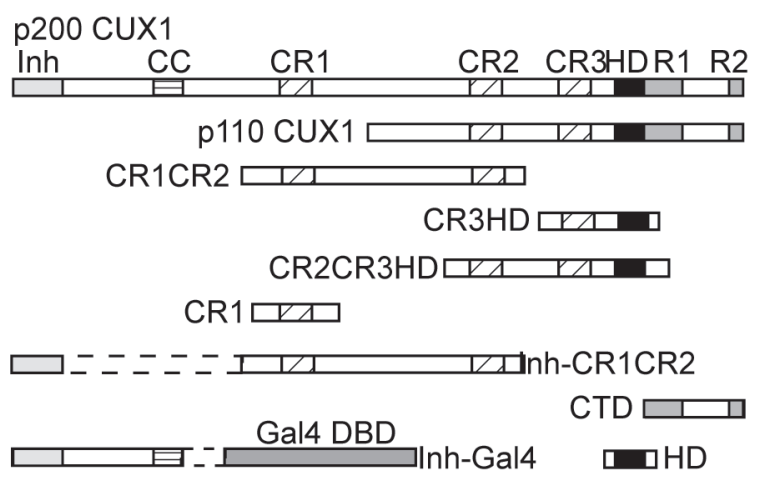

C

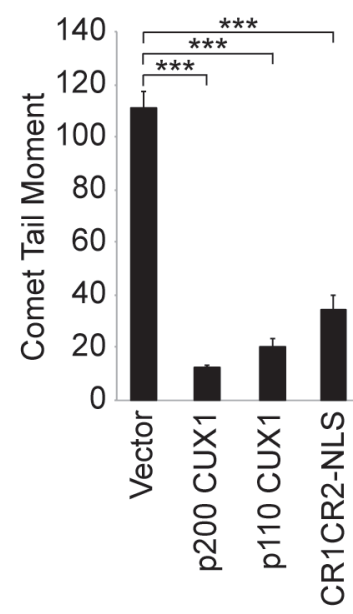

$\mathrm{F}$

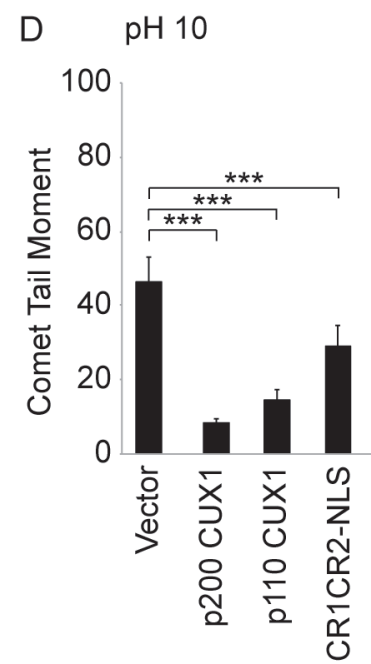

CUX1- MEFs
B

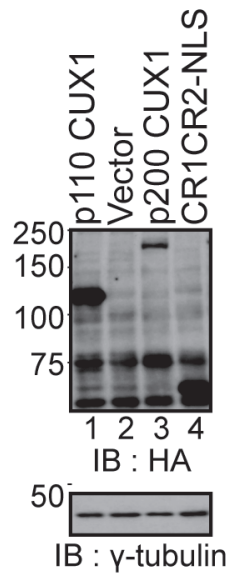

E

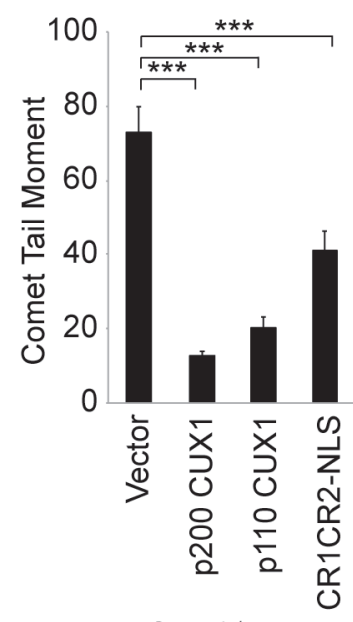

CUX1-1- MEFs
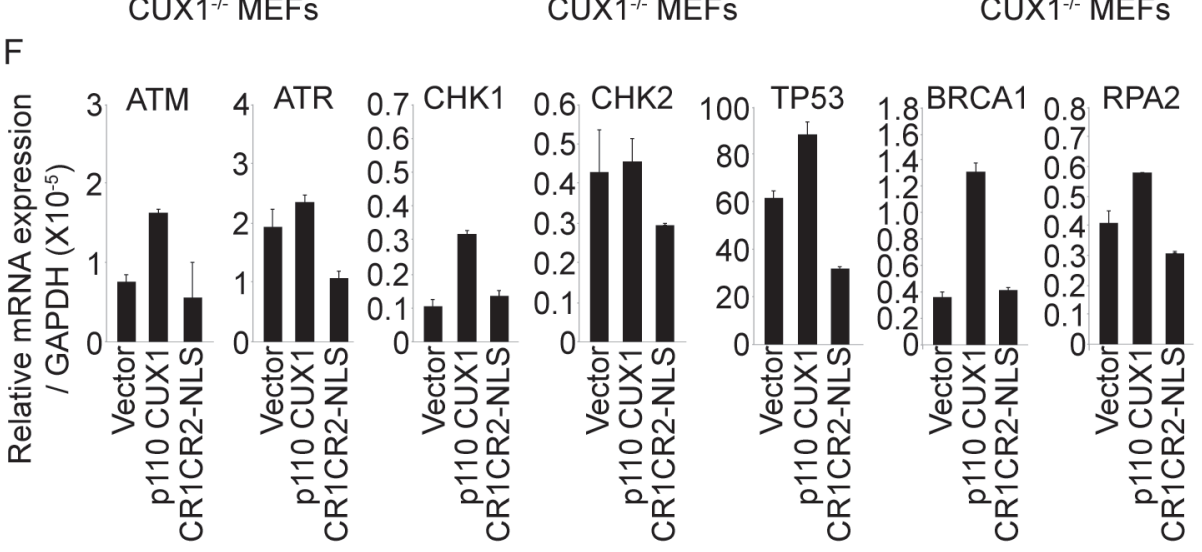

Figure 2: Rescue of DNA repair defect by recombinant CUX1 proteins. (A) Schematic representation of CUX1 proteins used in this study. Note that the proteins expressed in bacteria contain a histidine tag at their N-terminus. The CR1CR2 expressed in mammalian cells contains in addition a nuclear localization signal at its C-terminus. Shown at the top are the functional domains: Inh, auto-inhibitory domain; CC, coiled-coil; CR1, CR2 and CR3, Cut repeat 1, 2 and 3; HD, Cut homeodomain; R1 and R2, repression domains 1 and 2. Note that the auto-inhibitory domain prevents binding by covalently linked DNA binding domains [35]. (B) Cux $1^{-/}$MEFs were cultured in $3 \%$ oxygen and stably infected with retroviruses expressing p200 CUX1-HA, p110 CUX1-HA, CR1CR2-NLS-HA or nothing (vector). Expression of recombinant CUX1 protein expression was analyzed by immunoblotting using HA antibodies. (C, $\mathbf{D}$ and $\mathbf{E})$ Comet assays were performed after 32 days of culture in three conditions as described in Figure 1. Comet tail moments were scored for at least 50 cells per conditions. Error bars represent standard error. ${ }^{* *} p<0.001$; Student's $t$-test. (F) mRNA levels of transcriptional targets of CUX1 involved in DNA damage responses. All mRNA levels were normalized to glyceraldehyde 3-phosphate dehydrogenase (GAPDH). The values are the mean of three measurements and error bars represent standard deviation. 


\section{CUX1 knockdown reduces the 8-oxoG cleavage activity of cell extract}

Since 8-oxoG is the most abundant DNA adduct following treatment with an oxidizing agent, we investigated the effect of CUX1 knockdown on the efficiency of cell extracts to process oligonucleotides containing an 8-oxoG base (see probe $\mathrm{A}$ in Figure S3A). Three independent cell lines were infected with a lentivirus expressing a doxycycline-inducible shRNA against CUX1. Upon treatment with doxycycline, CUX1 protein expression was substantially reduced in all 3 cell lines, but OGG1 levels remained unchanged (Figure $3 \mathrm{~A})$. In each of the three cell lines, CUX1 knockdown significantly reduced the efficiency of 8-oxoG removal in vitro (Figure 3B, lanes 2, 4 and 6).

\section{Interaction between CUX1 and OGG1}

Co-immunoprecipitation experiments demonstrated that CUX1 is able to form a complex with FLAG-tagged OGG1 in cells. The FLAG-OGG1 protein was detected by immunoblotting following immunoprecipitation with CUX1 antibodies (Figure 4A, lane 3). Reciprocally, the CUX1 protein was detected by immunoblotting following immunoprecipitation with FLAG antibodies in the presence and absence of ethidium bromide (Figure 4B, lane 7 and lane 9). Pull-down assays using purified GSTtagged OGG1 and a his-tagged CUX1 protein containing the CR1 and CR2 domains established that the two proteins were able to engage in a direct interaction (Figure $4 \mathrm{C}$, lane 6). Importantly, the interaction was maintained when the assay was performed in the presence of ethidium bromide or benzonase (Figure 4C, lanes 3 and 7).

\section{Cut repeats stimulate the glycosylase and AP-lyase activities of OGG1 in vitro}

Using 8-oxoG cleavage assays with purified proteins, we previously showed that various combinations of Cut repeats and the Cut homeodomain (CR1CR2, CR3HD and CR2CR3HD) are able to stimulate the glycosylase activity of OGG1 [16]. Since each of these recombinant proteins is able to bind to DNA with high affinity, a logical conclusion from these experiments is that high affinity DNA binding contributes to the stimulation of OGG1. Here, we performed structure/function analysis to test this notion and we further characterized the effect of CUX1 on distinct biochemical activities of OGG1. The glycosylase activity of OGG1 was stimulated in the presence of any recombinant CUX1 protein that contains one or more Cut repeats: CR1CR2, CR3HD, CR2CR3HD and CR1 (Figure 5A, compare lane 3 with 4, 5 and 6; Figure 5B, compare lane 2 with 3, 4 and 5). The stimulation of OGG1 appears to be specific to the Cut repeat domain since there was no effect of other regions of the CUX1 protein, including the carboxy-terminal domain (CTD) and the Cut homeodomain (HD) (Figure 5B, lanes 6 and 8). Also, we observed no stimulation by other DNA binding proteins, including the full-length estrogen-related receptor alpha (ERR-FL), the ERR DNA binding domain (ERR-DBD) or the Gal4 DNA binding domain (Figure 5A, lanes 7-8; 5B, lane 7). Electrophoretic mobility shift assays (EMSAs) confirmed that the ERR-FL and ERRDBD proteins were folded properly since they were able to bind to their cognate DNA binding site (Figure S2). Increasing the concentration of Cut repeat proteins led to increased OGG1 glycosylase activity (Figure 3SA, probe A; Figure S3B, cleavage assay).

The glycosylase and AP-lyase activities of OGG1 can be distinguished by incubating the oligonucleotides with or without $\mathrm{NaOH}$ at the end of the reaction. A timecourse comparison of the products generated in the presence of $\mathrm{NaOH}$ shows that OGG1 alone generates an increasing amount of abasic sites that are cleaved by alkali treatment (Figure 5C, lanes 3, 5, 7, 9). In the absence of $\mathrm{NaOH}$, only a small fraction of these abasic sites are converted to a single-strand break by the AP-lyase activity of OGG1 (Figure 5C, lanes 17, 15, 13, 11). These results are in agreement with previous studies reporting a weak AP-lyase activity of OGG1 on its own [33]. When reactions were carried out with CR1CR2 and OGG1, however, the amount of cleaved products in the presence or absence of $\mathrm{NaOH}$ were comparable indicating that the AP-lyase activity of OGG1 is stimulated by CR1CR2 (Figure 5C, compare lanes 4 and 18,6 and 16, 8 and 14, 10 and 12). Increasing the concentration of CR1CR2 led to higher OGG1 AP-lyase activity (Figure S3C, right panel). The ability of CR1CR2 to stimulate the glycosylase and AP-lyase activities of OGG1 was confirmed using oligonucleotides with a different DNA sequence (Figure S4). CR2CR3HD was also able to stimulate the AP-lyase activity of OGG1 (Figure 5D, compare lanes 5 and 2, 7 and 8). In contrast to Cut repeats, HOXB3, TCF-DBD, PPAR $\delta$ and the DNA binding domain of ERR $\alpha$ had very weak or no effect on the AP-lyase activity of OGG1 (Figure 5D, compare lane 2 with 3, 4, and 6; and 8 with 9). Importantly, CR2CR3HD and CR1CR2 were unable alone to cleave a probe containing an 8 -oxoG residue or an abasic site (Figure S5A and S5B).

\section{Cut repeats stimulate the formation of a Schiff- base intermediate and the binding of OGG1 to 8-oxoG DNA}

In the course of the reaction carried out by OGG1 on 8-oxoG-containing DNA, a Schiff-base intermediate is formed [34]. Figure 6 shows that CR1CR2 stimulates Schiff-base formation by OGG1. Since the Schiffbase is formed concomitantly with the excision of the base, these results suggest that Cut repeats may stimulate the glycosylase step or the binding of OGG1 to 
A

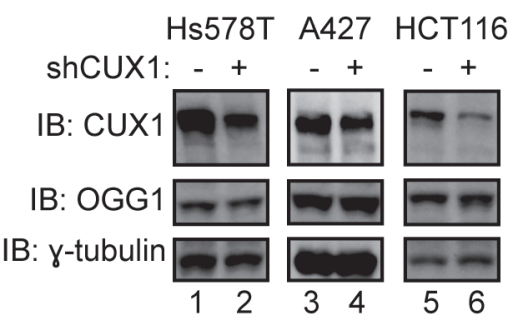

B

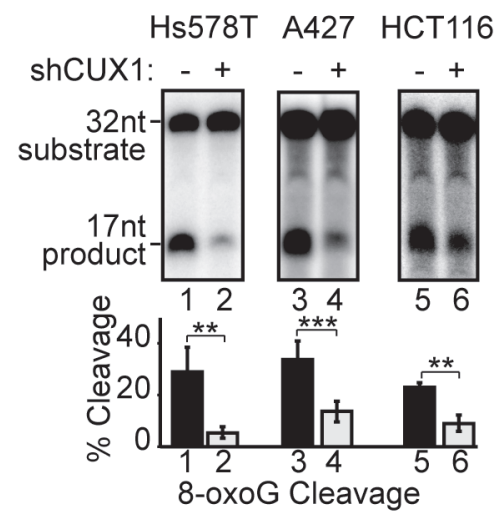

Figure 3: CUX1 knockdown reduces the 8-oxoG cleavage activity of human cell lines. Lentivirus expressing a doxycycline inducible shRNA against CUX1 was introduced in Hs578T, A427 and HCT116 cell lines. Doxycycline was added to the medium, total protein extracts were prepared after 4 days and used in immunoblotting analysis using the indicated antibodies (A) and 8-oxoG cleavage assays (B). The assays were conducted using $20 \mu \mathrm{g}$ of total proteins from each cell line and radiolabeled double-stranded oligonucleotides containing an 8-oxoG or a normal guanine base (see probe A in Figure S1A). Percentages of cleaved product from 3 independent experiments are shown below. Error bars represent standard error using Student's $t$-test, $* * * p<0.001 ; * * p<0.01$. From image scanning analysis, the extent of knockdown and cleavage inhibition were $88 \%$ and $81 \%$ in Hs578T, $35 \%$ and $58 \%$ in A427, and $68 \%$ and $60 \%$ in HCT116 cells.
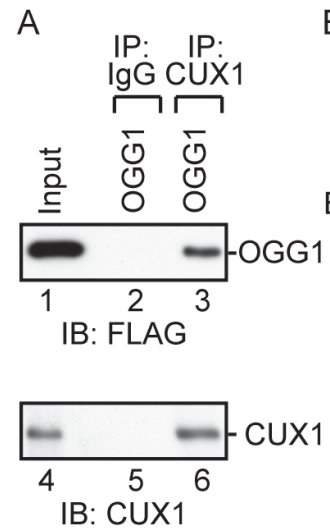

B
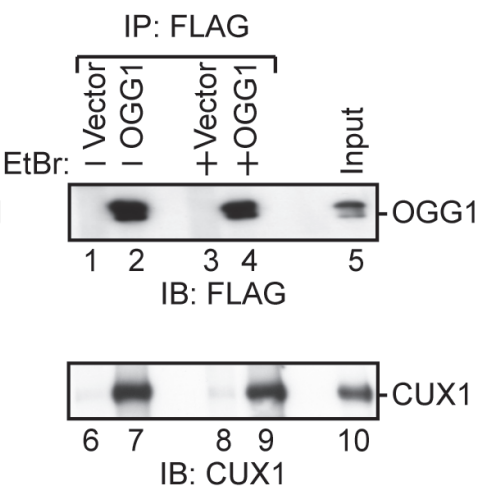

C

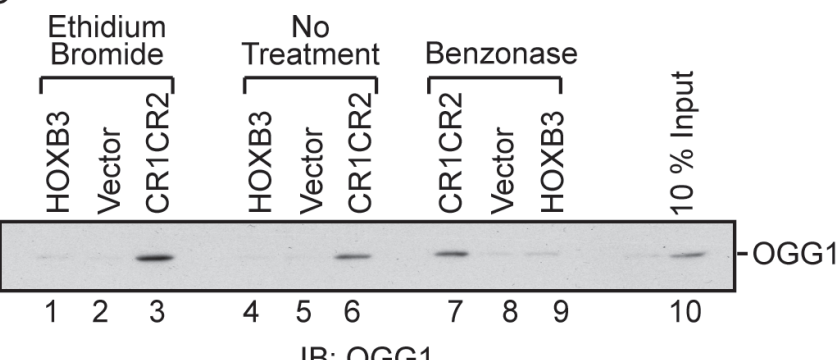

IB: OGG1

Figure 4: Interaction between OGG1 and CUX1. (A and B) 293T cells were transfected with CUX1 (CR2CR3HD; map in Figure 2A), FLAG-OGG1 or the empty vector, as indicated. (A) Total protein extracts were loaded on gel (input) or were submitted to immunoprecipitation with the indicated antibodies (Preimmune; IgG or CUX1) and then immunoblotted with FLAG and CUX1 antibodies. (B) Total protein extracts were submitted to immunoprecipitation with Flag antibodies in the absence or presence of ethidium bromide. (C) A pull-down assay was performed using purified GST-OGG1 and either beads bound to his-tagged CUX1-CR1CR2, HOXB3 or vector alone, followed by immunoblotting with anti-OGG1 in the presence and absence of ethidium bromide or after treatment of protein samples with benzonase. 
A

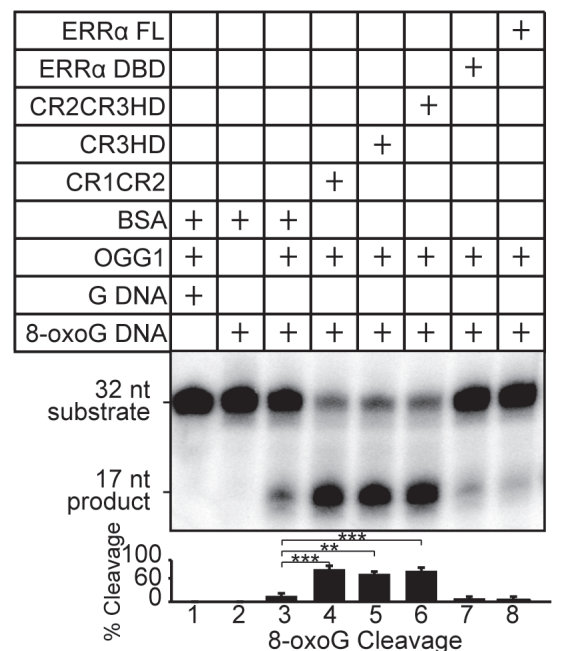

C

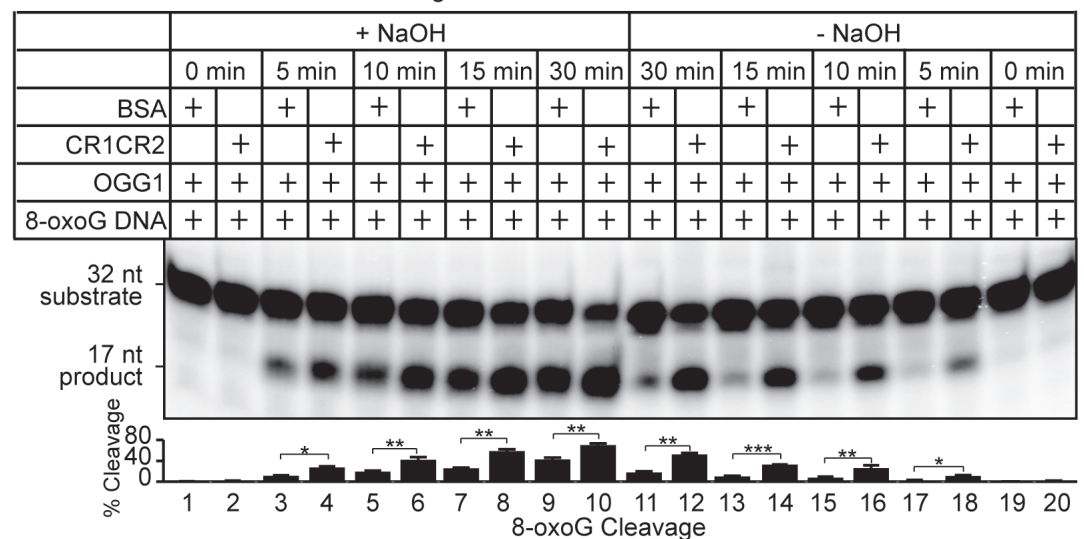

B

\begin{tabular}{|r|l|l|l|l|l|l|l|l|}
\hline $\mathrm{HD}$ & & & & & & & & + \\
\hline Inh-Gal4 & & & & & & & + & \\
\hline CTD & & & & & & + & & \\
\hline Inh-CR1CR2 & & & & & + & & & \\
\hline CR1CR2 & & & & + & & & & \\
\hline CR1 & & & + & & & & & \\
\hline BSA & + & + & & & & & & \\
\hline OGG1 & & + & + & + & + & + & + & + \\
\hline 8-oxoG DNA & + & + & + & + & + & + & + & + \\
\hline
\end{tabular}

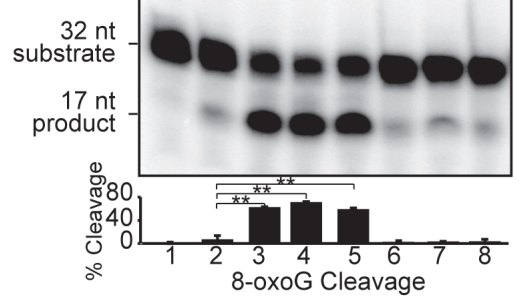

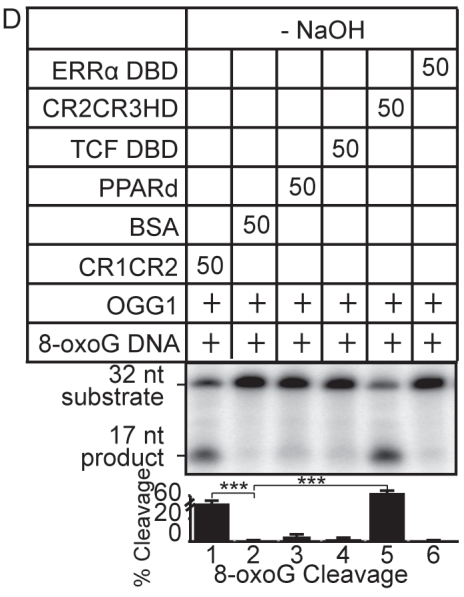
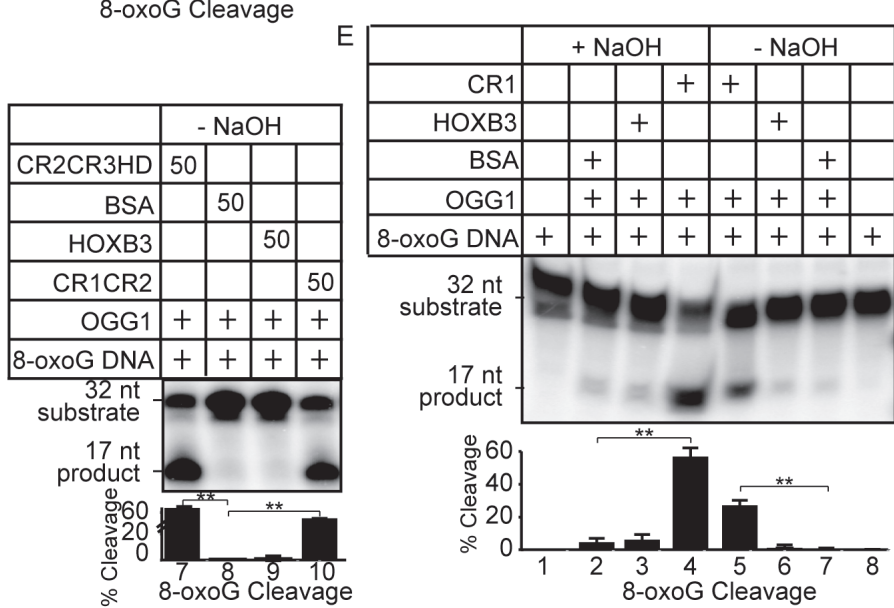

Figure 5: Cut repeats stimulate the glycosylase and AP-lyase activities of OGG1. Double-stranded oligonucleotides containing an 8-oxoG or an unmodified $G$ were radioactively end-labeled and used in cleavage and DNA binding assays. Sequences of probe A substrate and product are shown in Figure S1A. Percentages of cleaved product from 3 independent experiments are shown below each lane. Error bars represent standard error using Student's $t$-test, ${ }^{* * *} p<0.001 ;{ }^{* *} p<0.01 ;{ }^{*} p<0.05$. (A and B) The 8-oxoG cleavage assay was performed for $30 \mathrm{~min}$. using OGG1 (New England Biolabs, Ipswich, MA) and bacterially purified proteins as indicated. A diagrammatic representation of CUX1 proteins is shown in Figure 2A: CR1, CR1CR2, Inh-CR1CR2, CR2CR3HD, CR3HD, HD, CTD. Coomassie stains are presented in Figure S1B. ERR $\alpha$ FL is the full length estrogen-related receptor protein; ERR $\alpha$ DBD, the ERR $\alpha$ DNA binding domain; Inh-Gal4, the yeast Gal4 transcription factor fused to the CUX1 auto-inhibitory domain. (C) The 8-oxoG cleavage assay was performed using $50 \mathrm{nM}$ OGG1 and bacterially purified CUX1 CR1CR2. After $0,5,10,15,30$ min incubation at $37^{\circ} \mathrm{C}$, reactions were stopped, and DNA was submitted to treatment with $\mathrm{NaOH}(+\mathrm{NaOH})$ or not $(-\mathrm{NaOH})$. Reactions in the presence of $\mathrm{NaOH}$ monitor OGG1 glycosylase activity only, whereas reactions in the absence of NaOH reveal OGG1 glycosylase and AP-lyase activities. (D) The 8-oxoG cleavage assay was performed for $30 \mathrm{~min}$. with OGG1 and the indicated proteins and was stopped without treatment with $\mathrm{NaOH}$. (E) The 8-oxoG cleavage assay was performed using $50 \mathrm{nM}$ OGG1 and bacterially purified CUX1 CR1. The reaction was incubated for 30 min at $37^{\circ} \mathrm{C}$ and the DNA was treated either $\mathrm{NaOH}(+\mathrm{NaOH})$ or not $(-\mathrm{NaOH})$ prior to migration on the gel. 


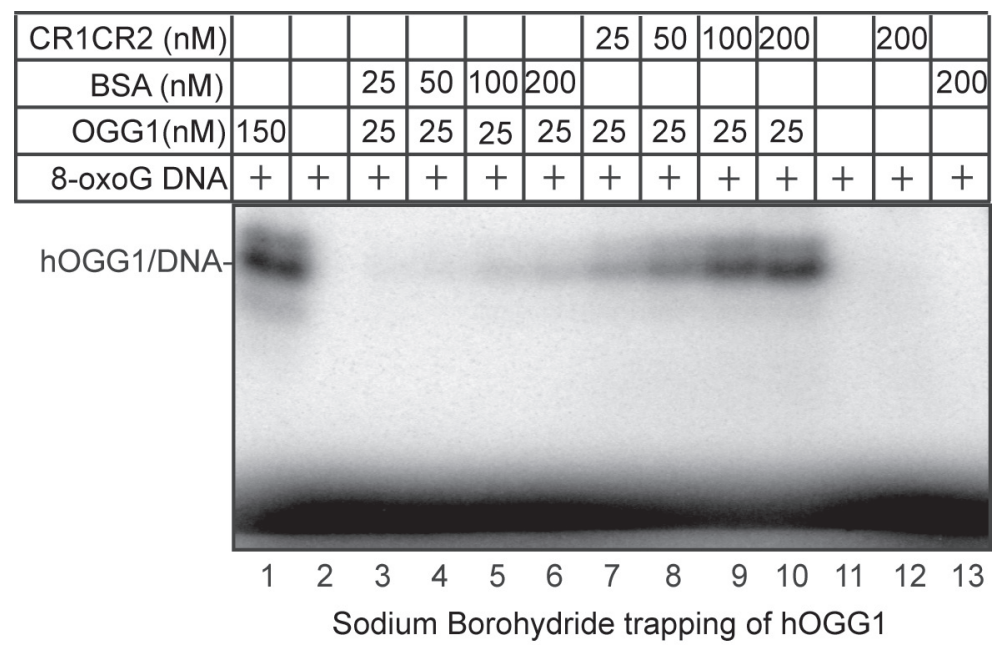

Figure 6: Sodium borohydride trapping of OGG1 enzyme in the presence of CR1CR2. 5'-end-labeled 32-mer duplex containing an 8-oxoG was incubated with hOGG1 and CR1CR2 or BSA at the indicated concentrations. After incubation at $37^{\circ} \mathrm{C}, 50$ $\mathrm{mM}$ sodium borohydride was added. The reactions were pursued for another $5 \mathrm{~min}$ at $37^{\circ} \mathrm{C}$. After termination of the reaction, the trapped complexes were separated from free substrate by $10 \%$ SDS-PAGE gel.

8-oxoG-containing DNA. Electrophoretic mobility shift assays (EMSAs) were performed using oligonucleotides that contain an 8-oxoG or a $\mathrm{G}$ base (probe A, Figure S3A), and OGG1 in the presence or absence of CR1CR2, CR2CR3HD or CR3HD. Each of these CUX1 recombinant proteins stimulated the binding of OGG1 to the probe containing an 8-oxoG, but not to probe containing a normal $\mathrm{G}$ base (Figure 7A, CR1CR2, compare lanes 1 and 2; CR2CR3HD, compare lanes 7 and 8; CR3HD, compare lanes 12 and 13). Note that the CUX1 recombinant proteins also generate a retarded complex, which in the case of CR3HD co-migrates with that of OGG1 (Figure $7 \mathrm{~A}$, lane 14). However, the mobility of the complex produced by OGG1 was not altered in the presence of any CUX1 protein, suggesting that OGG1 and CUX1 do not form a ternary complex with DNA. We noted that HOXB3 was also able to stimulate the binding of OGG1 to 8-oxoG DNA, albeit weakly (Figure 7C, lane 2). However, HOXB3 did not stimulate OGG1 enzymatic activity (Figure 5D, lane 9).

\section{Stimulation of OGG1 in vitro does not require high affinity DNA binding by Cut repeats}

A single Cut repeat cannot bind to DNA with high affinity when expressed as a monomer [27]. We confirmed these findings using oligonucleotides containing the CUX1 consensus binding site and his-tagged CUX1 proteins containing one or two Cut repeat(s). The CR1 protein generated only a weak retarded complex, whereas the CR1CR2 protein generated a strong retarded complex (Figure 7B, lanes 1 and 2). Yet, CR1 was able to stimulate the binding of OGG1 to probe A (Figure 7C, compare lane 13 with 11), the glycosylase activity of OGG1 (Figure 5B, compare lane 3 with 2), and its AP-lyase activity (Figure $5 \mathrm{E}$, compare lane 5 with 7). To confirm that the ability to bind DNA with high affinity is not required for Cut repeats to activate OGG1, we prepared a protein containing CR1CR2 fused to the N-terminal auto-inhibitory domain CUX1 (Inh-CR1CR2) [35]. The auto-inhibitory domain greatly reduced the binding of CR1CR2 to the CUX1 consensus binding site (Figure 7B, compare lanes 2 and 3). The Inh-CR1CR2 protein did not generate a detectable retarded complex with the 8-oxoG-containing probe $\mathrm{A}$ and did not reduce the amount of free probe (Figure $7 \mathrm{C}$, lane 15). Yet, the Inh-CR1CR2 protein was still able to increase the binding of OGG1 to 8-oxoG DNA and stimulate its enzymatic activity (Figure 7C, compare lane 16 with 11; Figure $5 \mathrm{~B}$, compare lane 5 with 2 ). In summary, these results demonstrate that a single Cut repeat is sufficient to stimulate several biochemical activities of OGG1 and that the stimulation of OGG1 can be dissociated from the high affinity DNA binding property of Cut repeats.

\section{The proliferation block of Cux $1^{-/-}$MEFs in $20 \%$ oxygen is rescued by CUX1 and by the Cut repeats 1 and 2}

Having established that ectopic expression of recombinant CUX1 proteins can restore efficient repair of oxidative DNA damage in $\mathrm{Cux}^{-/}$MEFs (Figure 2), we next investigated whether the proliferation block in $20 \%$ oxygen could also be rescued. When switched to $20 \%$ oxygen, $\mathrm{Cux}^{-1 /}$ MEFs carrying the empty vector divided no more than two to three times between days 30 and 49 (Figure 8). While this rate of proliferation is very modest, it is already better than what we observed we earlier cultures of $\mathrm{Cux}^{-/-}$MEFs (Figure 1A). This 
A

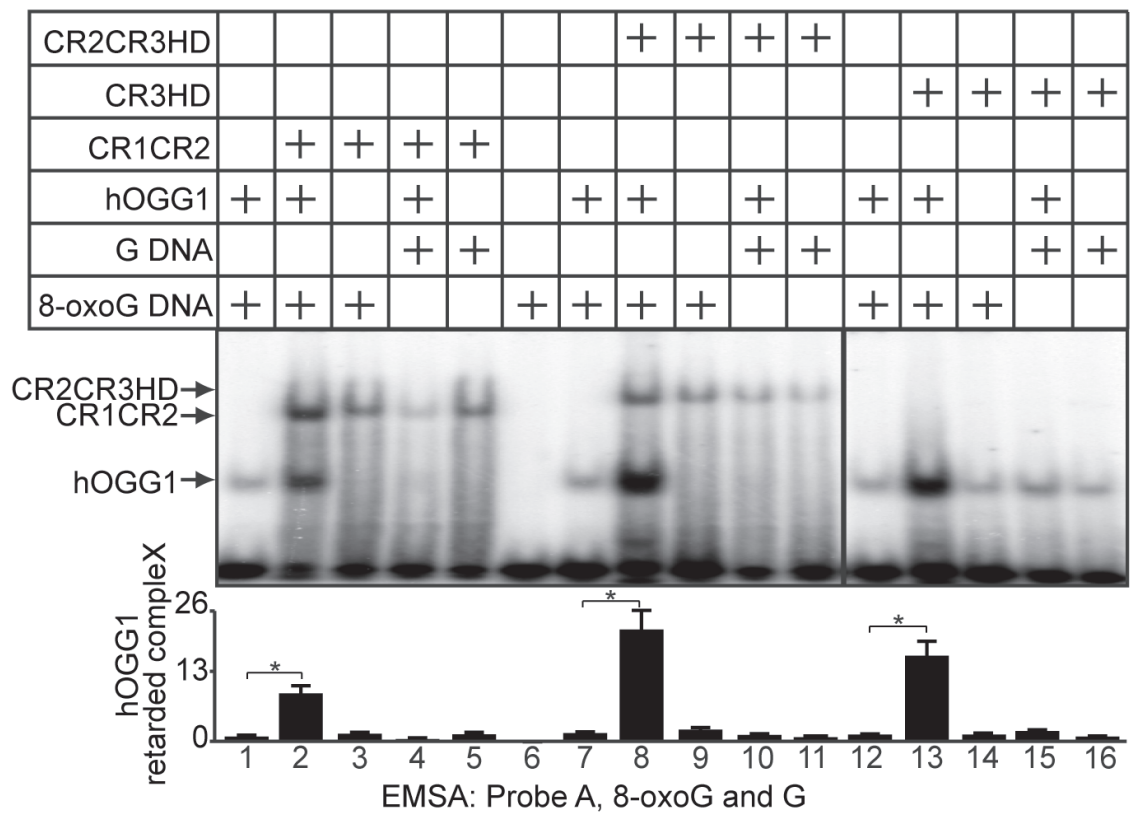

B

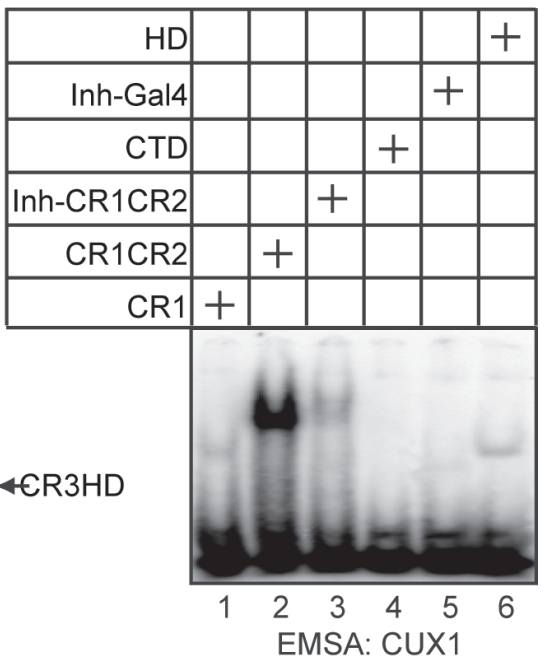

C

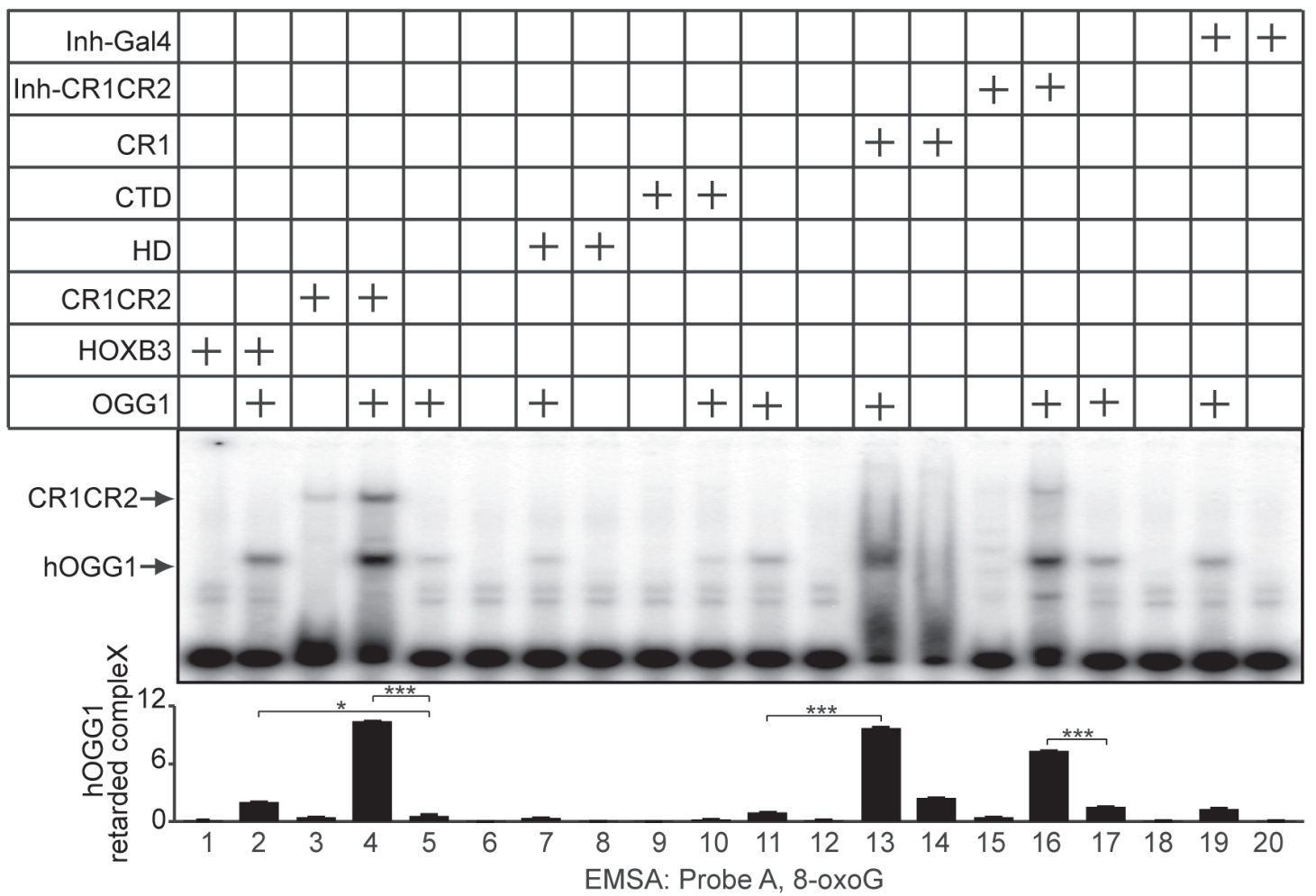

Figure 7: DNA Binding properties of Cut repeats and OGG1. EMSA was performed using OGG1 and/or bacterially purified proteins, as indicated. (A) The oligonucleotides correspond to probe A and contain an 8-oxoG or an unmodified G (Figure S1A). (B) The oligonucleotides contain a CUX1 consensus binding sites (Figure S2D). (C) The oligonucleotides correspond to probe A and contain an 8-oxoG (Figure S1A).

is likely due to the adaptive or mutagenic events that eventually enable MEFs to proliferate in $20 \%$ oxygen [4]. Strikingly, however, ectopic expression of both p200 CUX1 and CR1CR2-NLS completely rescued the proliferation defect of $\mathrm{Cux}^{-/}$MEFs in $20 \%$ oxygen
(Figure 8). Together, results presented in Figures 2 and 8 show that ectopic expression of recombinant CUX1 proteins in $\mathrm{Cux}^{-/-}$MEFs prevents the gradual increase in DNA damage and restores the capacity to proliferate in $20 \%$ oxygen. 


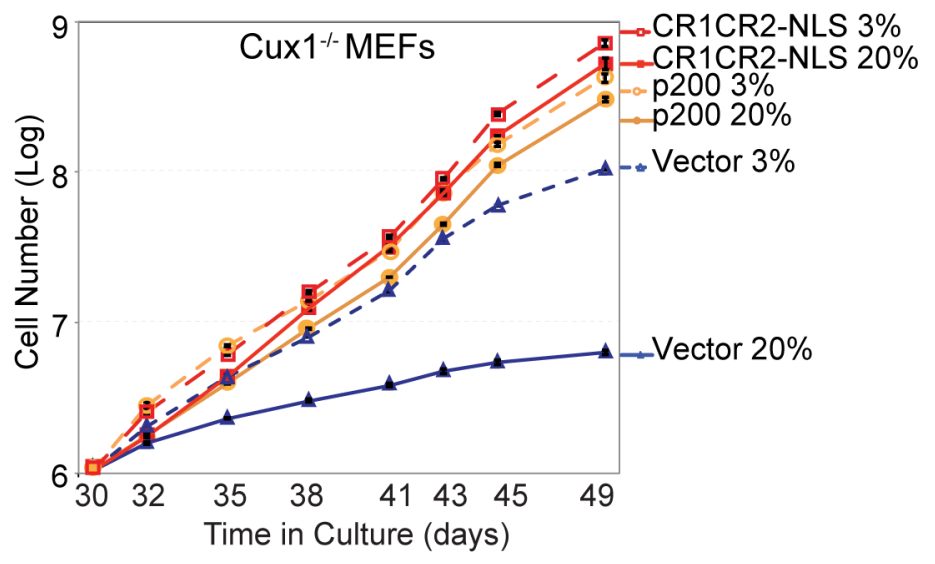

Figure 8: The proliferation block of $\mathrm{Cux}^{-/-}$MEFs in $20 \%$ oxygen is rescued by CUX1 and by the Cut repeats 1 and 2. $\mathrm{Cux}^{-/-}$MEFs were stably infected in 3\% oxygen with a retrovirus expressing p200 CUX1, CR1CR2-NLS or an empty vector. Following selection, cells were maintained in 3\% or $20 \%$ oxygen and counted over a period of 19 days, from days 30 to 49 .

\section{DISCUSSION}

RNAi-mediated knockdown and gene inactivation demonstrated that CUX1 is required for efficient repair of oxidative DNA damage, while base excision repair assays established that Cut repeat domains can increase the binding of OGG1 to 8-oxoG-containing DNA and stimulate both its glycosylase and AP-lyase activities (Figures 1, 3, 5 and 6). Based on these results, we propose that the p200 CUX1 protein serves as an accessory factor in the sub-pathway of base excision repair that removes oxidized purines.

Cellular senescence is believed to function as a tumor suppression mechanism, yet the senescenceassociated secretory phenotype can promote cancer development and progression by stimulating the proliferation of tumor cells, inducing an epithelial-tomesenchymal transition or protecting neighboring cells from the effects of chemotherapy [1]. Similarly, CUX1 belongs to this class of cancer genes that can both protect against cancer and promote cancer development and progression depending on physiological context [14]. It remains to be demonstrated whether the DNA repair function of CUX1 contribute to its role as a tumor suppressor, however, it is clear that RAS-driven cancer cells exploit this function of CUX1 to avoid senescence and continue to proliferate in spite of elevated levels of reactive oxygen species [16].

The finding that $\mathrm{Cux}^{-1-}$ MEFs accumulate DNA damage and exhibit a drastic proliferation defect in $20 \%$ oxygen suggests that the role of CUX1 in base excision repair will be particularly important in situations of oxidative stress and in cell types that consume more oxygen. Neurons have very high rates of oxygen metabolism due to their high glucose requirement and the dependence on aerobic oxidation of glucose as their source of energy [36]. Indeed, experimental evidence indicates that defective base excision repair can promote post-mitotic neuronal cell death and neurodegenerative disease $[9,37,38]$. In particular, defective base excision repair was demonstrated in brain from individuals with Alzheimer's disease and amnestic mild cognitive impairment [39]. Interestingly, gene duplication during evolution led to the existence of two CUX genes. While CUX1 is expressed ubiquitously, CUX2 exhibits neural-specific expression [40]. Future studies should investigate the status of CUX1 and its neuronspecific homolog, CUX2, in the aging brain and evaluate the pertinence of therapeutic intervention employing drugs that mimic the effect of Cut repeats on OGG1.

We can envisage a number of mechanisms by which Cut repeats stimulate the binding of OGG1 to DNA that contains an 8-oxoG lesion, in the absence of a high affinity CUX1 binding site (Figure 7). Cut repeats may bind to 8-oxoG residues long enough to promote cooperative binding with OGG1, however, we did not observe any retarded complex that corresponds to a ternary complex involving DNA, OGG1 and CUX1 (Figure 7A and 7C). It is possible that Cut repeats transiently alter the conformation of DNA to facilitate the recognition of 8-oxoG by OGG1 or, as suggested from previous studies, help OGG1 distort DNA while searching for damaged bases [41]. A third possibility, that does not exclude the others, is that Cut repeats induce an allosteric change in OGG1 itself. This notion is consistent with structural studies reporting conformational transitions of OGG1 associated with its biochemical activities ([42-45], reviewed in [6]). Assuming it would be possible to trap a Cut repeat-OGG1 complex, structural analysis might be able to provide important insights on the mechanism by which 8-oxoG lesions are recognized and excised in cells. Moreover, we suggest that it should be possible to identify small molecules that reproduce the effects of Cut repeats on OGG1. Indeed, previous studies using oligonucleotide substrates containing a specific lesion and attached to a fluorescent moiety have established the feasibility of performing high throughput screening assays [46, 47]. 
The discovery that CUX1 plays a role in base excision repair by stimulating the function of OGG1 has important implications beyond the repair of 8-oxoG lesions. The possibility that the function of DNA glycosylases could be facilitated by DNA binding proteins has not previously been thoroughly investigated. Indeed, in short-lived organisms with a small genome there is probably no need for ancillary proteins in base excision repair. In organisms with a large genome, however, we can envisage the benefit of having transcription factors participate in the maintenance of genome integrity. As their primary role is to scan the genome to determine which regions should be expressed and which ones should remain silent, transcription factors are well positioned to help in the recognition and repair of altered bases. In support of this notion, the YB-1 transcription factor has previously been reported to stimulate the base excision activity of NEIL2 and NTH1 [48, 49], while the architectural transcription factor HMGB1 was shown to stimulate the strand incision activity of APE1 [50]. The precedents set by CUX1, YB-1 and HMGB1 will justify further investigations into distinct classes of DNA binding proteins that participate in the repair of specific types of base damage. We note that the mammalian genome contains several hundred coding sequences for DNA binding domains, several of which with ill-defined transcriptional functions. We speculate that some DNA binding proteins that are present at more than 100,000 molecules per cell, like CUX1, function in processes other than transcription.

\section{MATERIALS AND METHODS}

\section{Cell culture and virus production}

Primary mouse embryonic fibroblasts (MEFs) were grown at $37^{\circ} \mathrm{C}, 5 \% \mathrm{CO}_{2}$ and $3 \% \mathrm{O}_{2}$ unless otherwise indicated. Lentiviruses and retroviruses were produced as previously described [16].

\section{Bacterial protein expression}

Expression of his- or GST-tagged fusion proteins containing CUX1 peptides [27], peroxisome proliferatoractivated receptor $\delta$ (PPAR $\delta$, Addgene plasmid 16548 [51]), transcription factor 4 DNA binding domain (TCF DBD, Addgene plasmid 16488 [52]), homeodomain protein B3 (HOXB3, Addgene plasmid 8524 [53]) was induced with isopropyl- $\beta$-D-thiogalactopyranoside in the BL21 strain of Escherichia coli. In the case of histagged fusion proteins to be used with OGG1, several buffer exchanges were carried in $3-\mathrm{kDa}$ molecular weight cut-off dialysis membrane (Amicon Ultra, Millipore) to bring down imidazole concentration to less than $0.1 \mu \mathrm{M}$.

\section{Cell proliferation}

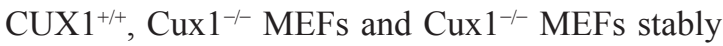
expressing p200, CR1CR2 or carrying an empty vector were plated in either $3 \% \mathrm{O}_{2}$ or atmospheric $\mathrm{O}_{2}$ at a density of $5 \times 10^{5}$ cells in a T75 flask. Cells were trypsinized and counted on a hemocytometer at every passage. Each time point was done in triplicate, and the averages \pm standard deviations were calculated. Experiments were repeated three times, and a representative experiment is shown.

\section{Cell viability assays}

$5 \times 10^{4} \mathrm{CUX}^{+/+}$and $\mathrm{Cux} 1^{-/-}$MEFs were cultured in $3 \% \mathrm{O}_{2}$ and incubated in medium containing various concentration of $\mathrm{H}_{2} \mathrm{O}_{2}$ (Sigma) for $60 \mathrm{~min}$, and then cultured in fresh medium for another $24 \mathrm{~h}$. Cells were trypsinized and counted on a hemocytometer in the presence of trypan blue. Only unstained living cells were counted. Experiments were repeated three times, each concentration of oxidizing agents were done in triplicate, and the averages \pm standard deviations were calculated.

\section{Single-cell gel electrophoresis}

For $\mathrm{H}_{2} \mathrm{O}_{2}$ treatment, cells at $\sim 80 \%$ confluence were treated with $50 \mu \mathrm{M} \mathrm{H}_{2} \mathrm{O}_{2}$ on ice for $20 \mathrm{~min}$. After treatment, cells were allowed to recover at $37^{\circ} \mathrm{C}$ in fresh medium for the indicated periods of time before harvesting. Comet assays were carried out using pre-coated slides according to manufacturer protocol (Trevigen, MD, USA). The slides were stained with propidium iodide and visualize with Axiovert 200M microscope with an LSM 510 laser module (Zeiss). Comet tail moments were measured on a minimum of 50 cells using the CometScore software (TriTeck Corp).

\section{In vitro binding assay}

Bacterially expressed his-tagged CUX1-CR1CR2 and HOXB3 proteins as well as proteins from bacteria carrying the empty his-tag vector were bound to Dynabeads magnetic beads (Life technologies) and incubated overnight with $100 \mathrm{ng}$ of purified GSTOGG1 proteins. As indicated, some binding assays were performed on lysates pretreated with $65 \mathrm{U} / \mathrm{ml}$ of benzonase (Novagen) for $15 \mathrm{~min}$ at $37^{\circ} \mathrm{C}$ or in the presence of 100 $\mu \mathrm{g} / \mathrm{ml}$ of ethidium bromide. The samples were washed five times and separated by SDS-PAGE followed by immunoblotting with anti-OGG1 antibody.

\section{In vitro 8-oxoG cleavage assay}

Cleavage reactions with bacterially purified proteins were conducted using $50 \mathrm{nM}$ hOGGl (New England Biolabs, Ipswich, MA), and $50 \mathrm{nM}$ of BSA or the indicated 
proteins, unless otherwise indicated, in $25 \mathrm{mM} \mathrm{NaCl}$, $10 \mathrm{mM}$ Tris (pH 7.5), $1 \mathrm{mM} \mathrm{MgCl}, 5 \mathrm{mM}$ EDTA (pH 8.0), $5 \%$ glycerol, $1 \mathrm{mM}$ of DTT and $1 \mathrm{pmol}$ of ${ }^{32} \mathrm{P}$-radiolabeled double-stranded oligonucleotides containing an 8-oxoG base (Figure S3A). Note that when using his-tagged fusion proteins, it is important at the end of the purification to carry several buffer exchanges in order to reduce imidazole concentration. In our hands, OGG1 is stimulated by imidazole at concentrations above $0.4 \mathrm{mM}$. Reactions with total cell extracts were performed as described by Paz-Elizur et al. [54] with slight modification. Briefly, $20 \mu \mathrm{g}$ of total proteins and $0.5 \mathrm{pmol}$ of ${ }^{32} \mathrm{P}$ radiolabeled oligonucleotides were used with $100 \mathrm{ng}$ of poly(dI-dC) as a nonspecific competitor DNA. In both assays, cleavage reactions were performed at $37^{\circ} \mathrm{C}$ as previously described. The DNA was loaded on a pre-warmed $20 \%$ polyacrylamide-urea gel (19:1) and separated by electrophoresis in Tris-borate and EDTA (TBE; pH 8.0) at constant 20 mAmp.

\section{Electrophoretic mobility shift assay (EMSA)}

EMSAs were performed as previously described [25], using Probe A (Figure S3A) or CUX1 consensus sequence (5'-TCGAGAAATGAAGCTTATCGATATCGTCTCGA$\left.3^{\prime}\right) .50 \mathrm{nM}$ of bacterially purified proteins were used in the reaction together with $60 \mathrm{ng}$ of poly $(\mathrm{dI}-\mathrm{dC})$ as a nonspecific competitor DNA.

\section{Sodium borohydride trapping of hogg1}

5'-end-labeled 32-mer duplex containing a 8-oxoG (50 nM) was incubated with hOGG1, and CR1CR2 or BSA at the indicated concentrations. After incubation at $37^{\circ} \mathrm{C}$ for $30 \mathrm{mins}, 50 \mathrm{mM}$ sodium borohydride was added and the reactions were pursued for another $15 \mathrm{~min}$ at $37^{\circ} \mathrm{C}$. The reaction was stopped in SDS sample loading buffer and heated for $5 \mathrm{~min}$ at $100^{\circ} \mathrm{C}$. The trapped complexes were separated from free substrate by $10 \%$ SDS-PAGE gel.

\section{ACKNOWLEDGMENTS}

We are grateful to several investigators for generously providing plasmids: Drs. N. Noren Hooten and Michele K. Evans (OGG1), Dr. Vincent Giguère (ERR), Dr. B. Vogelstein (PPAR $\delta$ and TCF DBD), Dr. G Sauvageau (HOXB3). We are indebted to Drs. T. Paz-Elizur and Z. Livneh for their protocol on cleavage assays. This research was supported by grant MOP- 326694 from the Canadian Institutes of Health Research to A.N. Infrastructure support and technical assistance were made possible with funds from the Canadian Foundation for Innovation and the Ministère du Développement économique, innovation et exportation Québec. Z.R. was supported by the Fonds de la recherche en santé du Québec (FRSQ). R.P., C.V. and S.D. were supported by studentships from the MICRTP, FRSQ and the Cole Foundation, respectively.

\section{REFERENCES}

1. Campisi J. Aging, Cellular Senescence, and Cancer. Annual Review of Physiology, Vol 75. 2013; 75:685-705.

2. Muñoz-Espín D, Serrano M. Cellular senescence: from physiology to pathology. Nat Rev Mol Cell Bio. 2014; 15:482-496.

3. Chen JH, Hales CN, Ozanne SE. DNA damage, cellular senescence and organismal ageing: causal or correlative? Nucleic Acids Res. 2007; 35:7417-7428.

4. Parrinello S, Samper E, Krtolica A, Goldstein J, Melov S, Campisi J. Oxygen sensitivity severely limits the replicative lifespan of murine fibroblasts. Nature cell biology. 2003; 5:741-747.

5. Grollman AP, Moriya M. Mutagenesis by 8-oxoguanine: an enemy within. Trends Genet. 1993; 9:246-249.

6. David SS, O'Shea VL, Kundu S. Base-excision repair of oxidative DNA damage. Nature. 2007; 447:941-950.

7. Demple B, Sung JS. Molecular and biological roles of Ape1 protein in mammalian base excision repair. DNA Repair (Amst). 2005; 4:1442-1449.

8. Wiederhold L, Leppard JB, Kedar P, Karimi-Busheri F, Rasouli-Nia A, Weinfeld M, Tomkinson AE, Izumi T, Prasad R, Wilson SH, Mitra S, Hazra TK. AP endonucleaseindependent DNA base excision repair in human cells. Mol Cell. 2004; 15:209-220.

9. Wilson DM, Bohr VA. The mechanics of base excision repair, and its relationship to aging and disease. DNA repair. 2007; 6:544-559.

10. Paz-Elizur $\mathrm{T}$, Ben-Yosef $\mathrm{R}$, Elinger $\mathrm{D}$, Vexler A, Krupsky M, Berrebi A, Shani A, Schechtman E, Freedman L, Livneh Z. Reduced repair of the oxidative 8-oxoguanine DNA damage and risk of head and neck cancer. Cancer Res. 2006; 66:11683-11689.

11. Paz-Elizur T, Krupsky M, Blumenstein S, Elinger D, Schechtman E, Livneh Z. DNA repair activity for oxidative damage and risk of lung cancer. J Natl Cancer Inst. 2003; 95:1312-1319.

12. Swartzlander DB, Bauer NC, Corbett AH, Doetsch PW. Regulation of base excision repair in eukaryotes by dynamic localization strategies. Progress in molecular biology and translational science. 2012; 110:93-121.

13. Paz-Elizur T, Sevilya Z, Leitner-Dagan Y, Elinger D, Roisman LC, Livneh Z. DNA repair of oxidative DNA damage in human carcinogenesis: potential application for cancer risk assessment and prevention. Cancer letters. 2008; 266:60-72.

14. Ramdzan ZM, Nepveu A. CUX1, a haploinsufficient tumour suppressor gene overexpressed in advanced cancers. Nature Reviews Cancer. 2014; 14:673-682.

15. Cadieux C, Kedinger V, Yao L, Vadnais C, Drossos M, Paquet M, Nepveu A. Mouse mammary tumor virus p75 and p110 CUX1 transgenic mice develop mammary tumors of various histologic types. Cancer Res. 2009; 69:7188-7197. 
16. Ramdzan ZM, Vadnais C, Pal R, Vandal G, Cadieux C, Leduy L, Davoudi S, Hulea L, Yao L, Karnezis AN, Paquet M, Dankort D, Nepveu A. RAS Transformation Requires CUX1-Dependent Repair of Oxidative DNA Damage. PLoS Biology. 2014; 12:e1001807.

17. Sansregret L, Vadnais C, Livingstone J, Kwiatkowski N, Awan A, Cadieux C, Leduy L, Hallett MT, Nepveu A. Cut homeobox 1 causes chromosomal instability by promoting bipolar division after cytokinesis failure. Proc Natl Acad Sci USA. 2011; 108:1949-1954.

18. Siam R, Harada R, Cadieux C, Battat R, Vadnais C, Nepveu A. Transcriptional activation of the Lats1 tumor suppressor gene in tumors of CUX1 transgenic mice. Molecular cancer. 2009; 8:60-70.

19. Ledford AW, Brantley JG, Kemeny G, Foreman TL, Quaggin SE, Igarashi P, Oberhaus SM, Rodova M, Calvet JP, Vanden Heuvel GB. Deregulated Expression of the Homeobox Gene Cux-1 in Transgenic Mice Results in Downregulation of p27(kip1) Expression during Nephrogenesis, Glomerular Abnormalities, and Multiorgan Hyperplasia. Dev Biol. 2002; 245:157-171.

20. Brantley JG, Sharma M, Alcalay NI, Heuvel GBV. Cux-1 transgenic mice develop glomerulosclerosis and interstitial fibrosis. Kidney International. 2003; 63:1240-1248.

21. Vanden Heuvel GB, Brantley JG, Alcalay NI, Sharma M, Kemeny G, Warolin J, Ledford AW, Pinson DM. Hepatomegaly in transgenic mice expressing the homeobox gene Cux-1. Mol Carcinog. 2005; 43:18-30.

22. Hulea L, Nepveu A. CUX1 transcription factors: from biochemical activities and cell-based assays to mouse models and human diseases. Gene. 2012; 497:18-26.

23. Sansregret L, Nepveu A. The multiple roles of CUX1: Insights from mouse models and cell-based assays. Gene. 2008; 412:84-94.

24. Harada R, Vadnais C, Sansregret L, Leduy L, Berube G, Robert F, Nepveu A. Genome-wide location analysis and expression studies reveal a role for p110 CUX1 in the activation of DNA replication genes. Nucleic Acids Res. 2008; 36:189-202.

25. Moon NS, Premdas P, Truscott M, Leduy L, Berube G, Nepveu A. S Phase-Specific Proteolytic Cleavage Is Required to Activate Stable DNA Binding by the CDP/Cut Homeodomain Protein. Mol Cell Biol. 2001; 21:6332-6345.

26. Vadnais C, Awan AA, Harada R, Clermont PL, Leduy L, Berube $G$, Nepveu A. Long-range transcriptional regulation by the p110 CUX1 homeodomain protein on the ENCODE array. BMC Genomics. 2013; 14:258.

27. Moon NS, Berube G, Nepveu A. CCAAT displacement activity involves Cut repeats 1 and 2, not the Cut homeodomain. J Biol Chem. 2000; 275:31325-31334.

28. Luo J, Emanuele MJ, Li D, Creighton CJ, Schlabach MR, Westbrook TF, Wong KK, Elledge SJ. A genome-wide
RNAi screen identifies multiple synthetic lethal interactions with the Ras oncogene. Cell. 2009; 137:835-848.

29. Luo J, Solimini NL, Elledge SJ. Principles of cancer therapy: oncogene and non-oncogene addiction. Cell. 2009; 136:823-837.

30. Nogueira V, Hay N. Molecular pathways: reactive oxygen species homeostasis in cancer cells and implications for cancer therapy. Clinical cancer research : an official journal of the American Association for Cancer Research. 2013; 19:4309-4314.

31. Vadnais C, Davoudi S, Afshin M, Harada R, Dudley R, Clermont PL, Drobetsky E, Nepveu A. CUX1 transcription factor is required for optimal ATM/ATR-mediated responses to DNA damage. Nucleic Acids Res. 2012; 40:4483-4495.

32. Truscott M, Raynal L, Premdas P, Goulet B, Leduy L, Berube G, Nepveu A. CDP/Cux stimulates transcription from the DNA polymerase alpha gene promoter. Mol Cell Biol. 2003; 23:3013-3028.

33. Hill JW, Hazra TK, Izumi T, Mitra S. Stimulation of human 8-oxoguanine-DNA glycosylase by AP-endonuclease: potential coordination of the initial steps in base excision repair. Nucleic Acids Res. 2001; 29:430-438.

34. Nash HM, Lu R, Lane WS, Verdine GL. The critical activesite amine of the human 8-oxoguanine DNA glycosylase, hOgg1: direct identification, ablation and chemical reconstitution. Chem Biol. 1997; 4:693-702.

35. Truscott M, Raynal L, Wang Y, Berube G, Leduy L, Nepveu A. The N-terminal region of the CCAAT displacement protein (CDP)/Cux transcription factor functions as an autoinhibitory domain that modulates DNA binding. J Biol Chem. 2004; 279:49787-49794.

36. Bruckner BA, Ammini CV, Otal MP, Raizada MK, Stacpoole PW. Regulation of brain glucose transporters by glucose and oxygen deprivation. Metabolism. 1999; 48:422-431.

37. Englander EW. Brain capacity for repair of oxidatively damaged DNA and preservation of neuronal function. Mechanisms of ageing and development. 2008; 129:475-482.

38. Wilson DM, McNeill DR. Base excision repair and the central nervous system. Neuroscience. 2007; 145:1187-1200.

39. Weissman L, Jo DG, Sørensen MM, de Souza-Pinto NC, Markesbery WR, Mattson MP, Bohr VA. Defective DNA base excision repair in brain from individuals with Alzheimer's disease and amnestic mild cognitive impairment. Nucleic Acids Res. 2007; 35:5545-5555.

40. Quaggin SE, Vandenheuvel GB, Golden K, Bodmer R, Igarashi P. Primary Structure, Neural-Specific Expression, and Chromosomal Localization Of Cux-2, a Second Murine Homeobox Gene Related to Drosophila Cut. J Biol Chem. 1996; 271:22624-22634. 
41. Chen L, Haushalter KA, Lieber CM, Verdine GL. Direct visualization of a DNA glycosylase searching for damage. Chemistry \& biology. 2002; 9:345-350.

42. Crenshaw CM, Nam K, Oo K, Kutchukian PS, Bowman BR, Karplus M, Verdine GL. Enforced presentation of an extrahelical guanine to the lesion recognition pocket of human 8-oxoguanine glycosylase, hOGG1. The Journal of biological chemistry. 2012; 287:24916-24928.

43. Banerjee A, Yang W, Karplus M, Verdine GL. Structure of a repair enzyme interrogating undamaged DNA elucidates recognition of damaged DNA. Nature. 2005; 434:612-618.

44. Bjørås M, Seeberg E, Luna L, Pearl LH, Barrett TE. Reciprocal flipping underlies substrate recognition and catalytic activation by the human 8-oxo-guanine DNA glycosylase. J Mol Biol. 2002; 317:171-177.

45. Bruner SD, Norman DP, Verdine GL. Structural basis for recognition and repair of the endogenous mutagen 8-oxoguanine in DNA. Nature. 2000; 403:859-866.

46. Simeonov A, Kulkarni A, Dorjsuren D, Jadhav A, Shen M, McNeill DR, Austin CP, Wilson DM. Identification and characterization of inhibitors of human apurinic/ apyrimidinic endonuclease APE1. PLOS ONE. 2009; 4:e5740

47. Thomson GJ, Hamilton NS, Hopkins GV, Waddell ID, Watson AJ, Ogilvie DJ. A fluorescence-based assay for the apurinic/apyrimidinic-site cleavage activity of human tyrosyl-DNA phosphodiesterase 1. Anal Biochem. 2013; 440:1-5.

48. Guay D, Garand C, Reddy S, Schmutte C, Lebel M. The human endonuclease III enzyme is a relevant target to potentiate cisplatin cytotoxicity in Y-box-binding protein-1 overexpressing tumor cells. Cancer science. 2008; 99: 762-769.

49. Das S, Chattopadhyay R, Bhakat KK, Boldogh I, Kohno K, Prasad R, Wilson SH, Hazra TK. Stimulation of NEIL2mediated oxidized base excision repair via YB-1 interaction during oxidative stress. J Biol Chem. 2007; 282:28474-28484.

50. Prasad R, Liu Y, Deterding LJ, Poltoratsky VP, Kedar PS, Horton JK, Kanno S, Asagoshi K, Hou EW, Khodyreva SN, Lavrik OI, Tomer KB, Yasui A, et al. HMGB1 is a cofactor in mammalian base excision repair. Mol Cell. 2007; $27: 829-841$.

51. He TC, Chan TA, Vogelstein B, Kinzler KW. PPARdelta is an APC-regulated target of nonsteroidal anti-inflammatory drugs. Cell. 1999; 99:335-345.

52. Morin PJ, Sparks AB, Korinek V, Barker N, Clevers H, Vogelstein B, Kinzler KW. Activation of beta-catenin-Tcf signaling in colon cancer by mutations in beta-catenin or APC. Science. 1997; 275:1787-1790.

53. Shen WF, Chang CP, Rozenfeld S, Sauvageau G, Humphries RK, Lu M, Lawrence HJ, Cleary ML, Largman C. Hox homeodomain proteins exhibit selective complex stabilities with Pbx and DNA. Nucleic Acids Res. 1996; 24:898-906.

54. Paz-Elizur T, Elinger D, Leitner-Dagan Y, Blumenstein S, Krupsky M, Berrebi A, Schechtman E, Livneh Z. Development of an enzymatic DNA repair assay for molecular epidemiology studies: distribution of OGG activity in healthy individuals. DNA repair. 2007; 6:45-60. 